\title{
Clinical Spectrum of Enteric Fever in Children: Study in a Tertiary Care Hospital, Dhaka, Bangladesh
}

\author{
Md. Mizanur Rahman ${ }^{1 *}$, ASM Nawshad Uddin Ahmed², Md. Jafar Iqbal ${ }^{3}$, Mohammad Abdullah Al Mamun ${ }^{4}$, Nazia
} Hossain $^{5}$, Md Atiqul Islam ${ }^{6}$

\footnotetext{
${ }^{1}$ Associate Professor and Head, Department of Paediatric Infectious Diseases and Community Paediatrics, Bangladesh Institute of Child Health (BICH), Dhaka Shishu (Children) Hospital, Dhaka, Bangladesh

${ }^{2}$ Professor \& Head, Department of Paediatric Endocrinology, Bangladesh Institute of Child Health (BICH), Dhaka Shishu (Children) Hospital, Dhaka, Bangladesh

${ }^{3}$ Resident Medical Officer, Department of Paediatric Infectious Diseases and Community Paediatrics, Bangladesh Institute of Child Health (BICH), Dhaka Shishu (Children) Hospital, Dhaka, Bangladesh

${ }^{4}$ Associate Professor, Division of Neonatal Cardiology, Department of Paediatric Cardiology, Bangladesh Institute of Child Health (BICH), Dhaka Shishu (Children) Hospital, Dhaka, Bangladesh

${ }^{5}$ Registrar, Department of Paediatric Infectious Diseases and Community Paediatrics, Bangladesh Institute of Child Health (BICH), Dhaka Shishu (Children) Hospital, Dhaka, Bangladesh

${ }^{6}$ Assistant Professor, Department of Paediatric Infectious Diseases and Community Paediatrics, Bangladesh Institute of Child Health (BICH), Dhaka Shishu (Children) Hospital, Dhaka, Bangladesh
}

DOI: $10.36347 /$ sjams.2020.v08i08.029

| Received: 16.08.2020 | Accepted: 23.08.2020 | Published: 30.08.2020

*Corresponding author: Dr. Md. Mizanur Rahman

Background: Enteric fever is a common public health problem in Bangladesh and it involves multiple symptoms. Enteric fever presents with variable clinical scenario. Objective: The aim of study was to evaluate the clinical spectrum of enteric fever in children. Methods: A prospective study was done in the department of Paediatric Infectious Diseases and Community Paediatrics, Dhaka Shishu (Children) Hospital, Dhaka, Bangladesh during the period from January 2018 to December 2018 who were clinically suspected to have enteric fever and had either a positive blood culture for Salmonella or a positive Widal test. Results: This study included 133 patients out of which 71 were males and 62 were females. The majority of patients were under 5 years. The age distribution of study population in depicted in table I and the sex distribution in Table-2. The most common presenting symptoms in our study was fever $(97.0 \%)$, abdominal pain $(39.8 \%)$, vomiting $(39.1 \%)$, diarrohea $(36.1 \%)$, and the common symptom was constipation $(18.8 \%)$ as depicted in table III. The most common physical findings was coated tongue $(74.4 \%)$, followed by toxic look (63.9\%), pallor (51.9\%), abdominal distension (15.0\%), abdominal tenderness (13.5\%), Rose spots $(14.3 \%)$, hepatomegaly $(16.5 \%)$, splenomeagly $(3.8 \%)$, and jaundice $(4.5 \%)$ as depicted in Figure-1. Complications were present in nine patients $(6.77 \%)$, Pneumonia was present in five patients $(3.76 \%)$, hepatitis in three patents $(2.25 \%)$ and encephalopathy in the patient $(0.75 \%)$ as shown in Table-4. Conclusions: Enteric fever is a common public health problem with fever as most common presenting symptom. Culture yield can be increased in enteric fever by drawing blood culture prior to administration of antibiotics. Ceftriaxone is highly efficacious as monotherapy in enteric fever.

Keywords: Enteric fever. Clinical spectrum, Paediatric infection.

Copyright @ 2020: This is an open-access article distributed under the terms of the Creative Commons Attribution license which permits unrestricted use, distribution, and reproduction in any medium for non-commercial use (NonCommercial, or CC-BY-NC) provided the original author and source are credited.

\section{INTRODUCTION}

Enteric fever causes prolonged illness characterized by bacteraemia. Sub-species enterica Serovar Typhi and Salmonella Paratyphi A, B and C [1]. It continues to be a global public health problem with over 21 million cases and at least 216,510 deaths occurring annually [2, 3]. Several studies in areas of endemicity and outbreaks have shown that about onequarter to one third of pediatric enteric fever cases are under five years of age, and that between $6 \%$ and $12 \%$ are under two years of age [4-7].

Enteric fever causes prolonged illness characterized by loacteriac. The clinical presentation varies from mild illness with low grade fever, malaise and slight dry cough to a serve clinical presentation with abdominal pain and multiple complications. Enteric fever usually presents with fever, anorexics, abdominal pain, diarrohea, constipation, weakness [8]. 
The presentation of Enteric fever may be more dramatic in children younger than 5 years type with comparatively higher rates of complications and hospitalization. Diarrhea, toxicity, and complications such as disseminated intravascular coagulopathy are also more common in infancy. If there is no complications, the symptoms and physical finding gradually improve within 2-4 weeks [9]. Our aim was to evaluate the clinical spectrum of Enteric fever in children admitted in the hospital.

\section{MeTHODS}

A prospective study was done at the department of Paediatric Infectious Diseases and Community Paediatrics Dhaka Shishu (Children) Hospital, Dhaka, Bangladesh during the period from January 2018 to December 2018. All the patients in the age group of 1 to 15 years with clinically suspected enteric fever and either Widal or Blood culture was positive were included in this study. All patients were subjected to detailed history and examination. Baseline investigations were done in all patients. In addition to baseline investigation blood culture and Widal test was done in all patients. Blood culture was done after taking proper aseptic precautions. Blood culture was done by BACT/ALERT Automated system and positive cultures were characterized using standard bacteriological procedures. Widel was done by the agglutination test. A titre of $\geq 1: 160$ to either 0 or $\mathrm{H}$ antigen in a single serum specimen was taken as indicator of typhoid fever.

Data were entered and analyzed using SPSS version 23. Data has been summarized using percentage and table.

\section{RESULTS}

This study included 133 patients out of which 71 were males and 62 were females. The majority of patients $81(60.2 \%)$ were under 5 years (Table-1) and Male were dominated in sex distribution 71(53.4\%) (Table-2). The most common presenting symptoms in our study was fever (97.0\%), abdominal pain (39.8\%), vomiting $(39.1 \%)$, diarrohea $(36.1 \%)$, and the common symptom was constipation $(18.8 \%)$ as depicted (Table$3)$. The most common physical findings was coated tongue $(74.4 \%)$, followed by toxic look $(63.9 \%)$, pallor (51.9\%), abdominal distension (15.0\%), abdominal tenderness $(13.5 \%)$, Rose spots $(14.3 \%)$, hepatomegaly $(16.5 \%)$, splenomeagly $(3.8 \%)$, and jaundice $(4.5 \%)$ as depicted (Figure-1). Complications were present in nine patients $(6.77 \%)$, Pneumonia was present in five patients $(3.76 \%)$, hepatitis in three (3) patients $(2.25 \%)$ and encephalopathy in one(1) patient $(0.75 \%)$ as shown (Table-4).

Table-1: Age distribution of the Enteric fever in children. $(n=133)$

\begin{tabular}{|l|l|l|}
\hline Age Group & No. Patients n=133 & \% \\
\hline$<60$ months & 81 & 60.2 \\
\hline$>60$ months & 53 & 39.8 \\
\hline
\end{tabular}

Table-2: Sex distribution of the Enteric fever in children. $(n=133)$

\begin{tabular}{|l|l|l|}
\hline Variables & No. Patients n=133 & \% \\
\hline Male & 71 & 53.40 \\
\hline Female & 62 & 46.60 \\
\hline
\end{tabular}

Table-3: Symptoms' of the Enteric fever in children. $(n=133)$

\begin{tabular}{|l|l|l|}
\hline Preventive Symptom & No. Patients n=133 & \% \\
\hline Fever & 129 & 97.0 \\
\hline Abdominal pain & 53 & 39.8 \\
\hline Vomiting & 52 & 39.1 \\
\hline Diarohaea & 48 & 36.1 \\
\hline Constipation & 25 & 18.8 \\
\hline
\end{tabular}

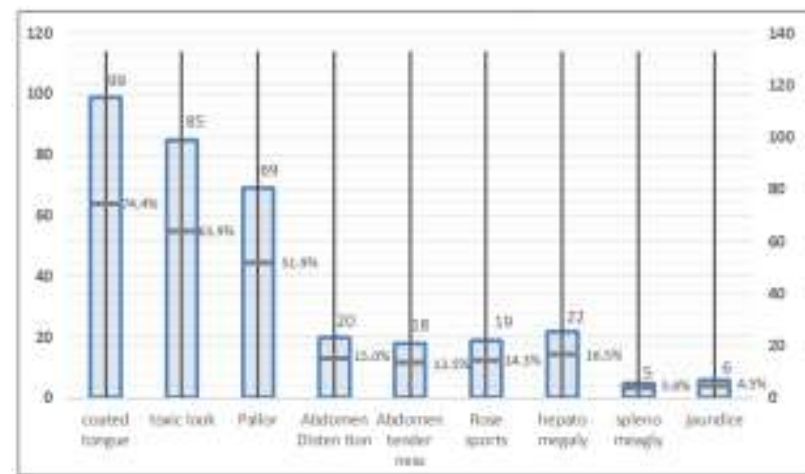

Fig-1: Graph of Physical sign of the Enteric fever in children ( $n=133)$ 
Table-4: Complications of the Enteric fever in children $(n=9)$

\begin{tabular}{|l|l|l|}
\hline Complications & No. Patients n=9 & \% \\
\hline Pneumonia & 5 & 3.76 \\
\hline Hepatitis & 3 & 2.25 \\
\hline Encephalopathy & 1 & 0.75 \\
\hline
\end{tabular}

\section{DisCUSSION}

Enteric fever is still a significant public health problem in developing countries. It is a dread disease because of its long course and associated complications if not detected and treated early. Typhoid fever is endemic in Bangladesh, where there is a high incidence in children [10].

In this study we found $60 \%$ of children were less then five years, which is also in agreement with an earlier of $43.9 \%$ prevalence rate in Cebn city, Phillipine [11]. The scene is that children are the most vulnerable group in environments where inadequate pure water supply and poor environmental hygine are problems. Fever who seen in almost all patients $(97 \%)$. Similar results ware seen in studies doneby Kundu $\mathrm{R}$ et al., Ganesh R et al., Walia M et al., and S Jog et al., [1215]. Vomiting was seen in $53(39.1 \%)$ patients which is similar to study done by S Jog et al., [15]. Diarrhoea was seen in $48(36.1 \%)$ which is comparable to study done by Ganesh et al., and S Jog et al., [13-15]. Abdominal pain was seen in $53(39.8 \%)$ patients and it different from study done by Abdus S. Bhat et al., [16] where they showed only $18.4 \%$ constipation was seen in $25(18.8 \%)$ which is comparable to studies done by Comeau et al and Taneja PN et al., $[17,18]$.

In this study coated tongue and toxic look were the most clinical findings. Coated tongue was seen in 99 (74.4\%) patients similar to studies done by R Modi and Iqbal et al., [19, 20]. Toxic look was seen in $85(63.9 \%)$ patients similar to study done by Sood and Taneja [21]. Pallor was seen in 69 patients $(51.9 \%)$ patients. Our study defer with Abdus S. Bhat et al., [16] study where they showed only $32.8 \%$. Hepatomeagly was seen in 22 (16.5\%) patients which is differ to studies done by $\mathrm{R}$ Modi Chowta MN et al., and Jeeyani $\mathrm{H}$ et al., [22, 19, 23 ]. Splenomeagly was seen in $5(3.8 \%)$ patients which is also dissimilar to studies done by S Jog et al., and Jeeyani $\mathrm{H}$ et al., $[15,23]$ Complications were seen in 9 $(6.77 \%)$ patients which is similar to study done by Jeeyani $\mathrm{H}$ et al., [23]. Pneumonia was seen in $5(3.76 \%)$ cases and hepatitis $3(2.25 \%)$ cases. Encephalopathy was seen in $1(0.75 \%)$ cases similar to study done by $\mathrm{Md}$. Salim et al., [24]. The mean time to defervescence was 5.5 days which is similar to studies done by S Jog et al., and Parry et al., [15, 25].

\section{Conclusion}

Enteric is a very common public health problem with fever as major presenting symptom. Blood culture yield can be increased by drawing blood sample prior to administration of antibiotics. Majority of enteric fever have uncomplicated course. Ceftriaxone is highly efficacious against enteric fever till date.

\section{REFERENCES}

1. Behrman RE, Kliegman RM, Jenson HB. Nelson Textbook of Pediatrics. 18th ed. Philadelphia: Elsevier; 2004:1386-1391.

2. Crump JA, Luby SP, Mintz ED. The global burden of typhoid fever. Bull World Health Organ. 2004;82(5):346-353

3. Jhon A Crump, Eric D Mintz. Global trends in typhoid and paratyphoid fever. Clinical infection. 2010; 50:241-46.

4. Crump JA, Youssef FG, Luby SP, Wasfy MO, Rangel JM, Taalat M, Oun SA, Mahoney FJ. Estimating the incidence of typhoid fever and other febrile illnesses in developing countries. Emerging infectious diseases. 2003 May;9(5):539.

5. Sinha A, Sazawal S, Kumar R, Sood S, Reddaiah VP, Singh B, Rao M, Naficy A, Clemens JD, Bhan MK. Typhoid fever in children aged less than 5 years. The Lancet. 1999 Aug 28;354(9180):734-7.

6. Brooks WA, Hossain A, Goswami D, Sharmeen AT, Nahar K, Alam K, Ahmed N, Naheed A, Nair GB, Luby S, Breiman RF. Bacteremic typhoid fever in children in an urban slum, Bangladesh. Emerging infectious diseases. $2005 \mathrm{Feb} ; 11(2)$ :326329.

7. Naheed A, Ram PK, Brooks WA, Hossain MA, Parsons MB, Talukder KA, Mintz E, Luby S, Breiman RF. Burden of typhoid and paratyphoid fever in a densely populated urban community, Dhaka, Bangladesh. International Journal of Infectious Diseases. 2010 Sep 1;14:e93-9.

8. David AP, Samual IM, Salmonellosis. In Harrison's principles of internal medicine. $19^{\text {th }}$ ed. Mcgraw; 2015:1049-57.

9. Bhutta ZA. Enteric Fever (Typhoid Fever). In: Behrman RE, Kliegman RM, Jenson HB, Stanton FB (eds). Nelson Textbook of Pediatrics. 20th ed. Philadelphia: WB Saunders; 2016:1388-1391.

10. Saha SK, BAQUI AH, Hanif M, Darmstadt GL, Ruhulamin M, Nagatake T, Santosham M, Black RE. Typhoid fever in Bangladesh: implications for vaccination policy. The Pediatric infectious disease journal. 2001 May 1;20(5):521-4.

11. Virginia V. Pate-Mesala and Manual Emerson S. Donaldo. Antimicrobial susceptibility of S. typhi isolated from government and private hospital in Cuba cita. Philippine journal of microbiology and infection disease. 1995; 26(1):5-8.

12. Kundu R, Ganguly N, Ghosh TK, Choudhury P, Shah RC. Diagnosis and management of malaria in 
children: recommendations and IAP plan of action. Indian Pediatr. 2005; 42(11):1101-1114.

13. Ganesh R, Janakiraman L, Vasanthi $T$, Sathiyasekeran M. Profile of typhoid fever in children from a tertiary care hospital in ChennaiSouth India. Indian J Pediatr. 2010; 77(10):10891092.

14. Walia M, Gaind R, Paul P, Mehta R, Aggarwal P, Kalaivani M. Age-related clinical and microbiological characteristics of enteric fever in India. Trans R Soc Trop Med Hyg. 2006; 100(10):942-948.

15. Jog S, Soman R, Singhal T, Rodrigues C, Mehta A, Dastur FD. Enteric fever in Mumbai--clinical profile, sensitivity patterns and response to antimicrobials. J Assoc Physicians India. 2008; 56:237-240.

16. Bhut AS, WANI JN, Yusuf S, Quresh UA. Clinical spectrum of enteric fever in children admitted to tertiay one hospital. Int $\mathbf{J}$ Contempt podiatry. $2020 \mathrm{Jul}$;7(7) 1530-1533.

17. Comeau JL, Tran TH, Moore DL, Phi CM, Quach C. Salmonella enterica serotype Typhi infections in a Canadian pediatric hospital: a retrospective case series. CMAJ Open. 2013;1(1):E56-E61. Published 2013 May 2.
18. Taneja PN, Ghai K. Clinical study of enteric fever. Indian Podiatry. 1997; 34(6):237-9.

19. Modi R. Clinical profile and reatment outcome of typhoid fever in children at a teaching hospital, Ahmadebad, Gujaat ata a teaching hospital, Ahmadebad, Gujrat, India. Int J Med sci Public Health. 2016; 5(2):212-6.

20. Iqbal SMJ. Clinical Spectrum of Typhoid Fever in Children. Pak J Medical Health Sci. 2004; 2004.

21. Sood SC, Taneja PN. Typhoid fever, clinical picture and diagnosis. Indian J Child Health. 1961; 10(2):69-76.

22. Chowta MN, Chowta NK. Study of clinical profile and antibiotic response in typhoid fever. Indian $\mathrm{J}$ Med Microbiol. 2005; 23(2):125-127.

23. Jeeyani HN, Prajapati BS, Bloch A. Enteric fever in children-clinical profile, sensitivity patterns and response to anti microbials. GCSMC J Med Sci. 2015;4(1):40-3.

24. Salim M, Hita SA, Shahid AT, Khahil MI, Hossain MN. Scholars J applied medical sciences. 2019; 7(12):393-9.

25. Parry CM, Hien TT, Dougan G, White NJ, Farrar JJ. Typhoid fever. N Engl J Med. 2002; 347(22):1770-1782. 